\title{
THE RESULTS OF PRACTICAL RESEARCH OF THE SEPARATOR IN AN EFFICIENT DESIGN THAT SEPARATES THE RAW COTTON FROM THE AIR
}

\author{
Ozod Rajabov ${ }^{1}$ \\ ${ }^{1}$ Associate Professor (PhD) of the Department \\ of Technological Machinery and Equipment, \\ Bukhara Engineering Technological Institute, \\ Bukhara, \\ Uzbekistan
}

\author{
Shukhrat Khayitov ${ }^{2}$ \\ 2,Master student of the Bukhara Engineering \\ Technological Institute, \\ Bukhara, \\ Uzbekistan
}

\author{
Mukhriddin Yokubov ${ }^{3}$ \\ ${ }^{3}$ Master student of \\ the Bukhara Engineering Technological Institute, \\ Bukhara, Uzbekistan
}

Article DOI: https://doi.org/10.36713/epra6098

\begin{abstract}
The article provides information on the main disadvantages of separators currently used in ginneries. The results obtained by identifying ways to overcome the above-mentioned shortcomings and introducing into the production of separators of new efficient design are also presented. The analysis of the results shows that the improved SXM inertial separator allows to preserve the natural properties of cotton by 15-20\% compared to the current SX separator, as well as to provide a stable and stable average of $15 \mathrm{t} / \mathrm{h}$.
\end{abstract}

KEYWORDS: raw cotton, separator, seed, mesh surface, air flow, vacuum - valve.

\section{INTRODUCTION}

Improving the efficiency of existing equipment and facilities in ginneries, improving the quality of products in many respects to meet the technical requirements for these devices, the correct choice of technological regulations and the correct observance of aerodynamic standards in pneumatic transport systems depends. Analysis of existing technological and aerodynamic conditions, selection and introduction of alternatives into production, production efficiency, identification of factors affecting the natural properties of cotton and finding ways to eliminate it, air separation device for cotton is available in SS-15A and SX separators The essence of this scientific work is the introduction of proposals for the elimination of deficiencies and the prevention of fiber loss and its application in production $[1,2]$.
An analysis of this topic and finding a solution to the problem arising from it is a comprehensive analysis of the SS-15A and SX separators, which are widely used in ginneries today. This is due to the fact that cotton, which is widely used today, damages the fiber and seeds, which are the main products of cotton transportation. Therefore, the main goal of this work is to identify ways to overcome the above shortcomings and the introduction of new technologies in production $[3,4]$.

\section{METHODS AND MATERIALS}

Currently, the SX separator is widely used in the ginning industry (Figure 1). The separator is designed as follows: separating chamber 1, return wall 2, inertial separation section 3, air inlet and outlet pipes 7 , cylindrical mesh surface 6 , separation shaft 8 , scraper 9 and vacuum valve 5 . Cylindrical mesh surface and the separation drum is mounted at a 
specified distance $(70-100 \mathrm{~mm})$ from the separation chamber.

The fact that the scrapers in the separating drum are interconnected with the air separating cotton prevents the cotton from accumulating in the separating chamber.

The principle of operation of the separator brand SX is based on the principle of operation of the pneumatic separator.

The main part of the seed cotton, which enters the air-separating chamber 1 , separates from the air flow as a result of hitting the return wall 2 and by its own inertia falls directly into the vacuum valve. A portion of the seed cotton is moved by the fan along with the air flow absorbed through the mesh surface, sticks to the cylindrical mesh surface, is cleaned with the scrapers of the separating drum and discharged into the vacuum valve.

Due to the use of SX separator, cotton seeds are not allowed to fall directly on the surface of the cylindrical mesh. As a result, a reduction in cotton entanglement and seed damage was achieved. In addition, the plane of the mesh surface is always clean, thus ensuring a constant aerodynamic resistance of the separator. Another advantage of the separator is that it consumes less energy.
Analysis of the SX separator shows that there is a partial loss of fiber during the separation of cotton from the air, which is $0.23 \mathrm{~kg} / \mathrm{h}$. As a result of the use of the separator, fiber loss is reduced by $0.17 \mathrm{~kg} / \mathrm{h}$ for high varieties and $0.83 \mathrm{~kg} / \mathrm{h}$ for low varieties $[5,6]$.

Improvements to the SX separator have been made in two main areas:

The first direction is to preserve the natural properties of the cotton falling into the vacuum-valve by distributing the cotton layer evenly along the working lengths of the vacuum-valve at the inlet of the separators. In this direction, the cotton layer is concentrated in the middle of the pipe by the centrifugal force, so that the main mass falls on the central part of the vacuum valve. For this purpose, it is advisable to install distribution and guidance devices for the cotton gin.

The second direction is to minimize the mass of cotton moving on the mesh surface by directing the separator by the inertia of the cotton mass moving from the inlet to the vacuum valve. Due to this, the natural properties of cotton are preserved. To do this, improve the design of the inlet pipes of the SX separator and provide aerodynamic process control $[7,8,9]$.

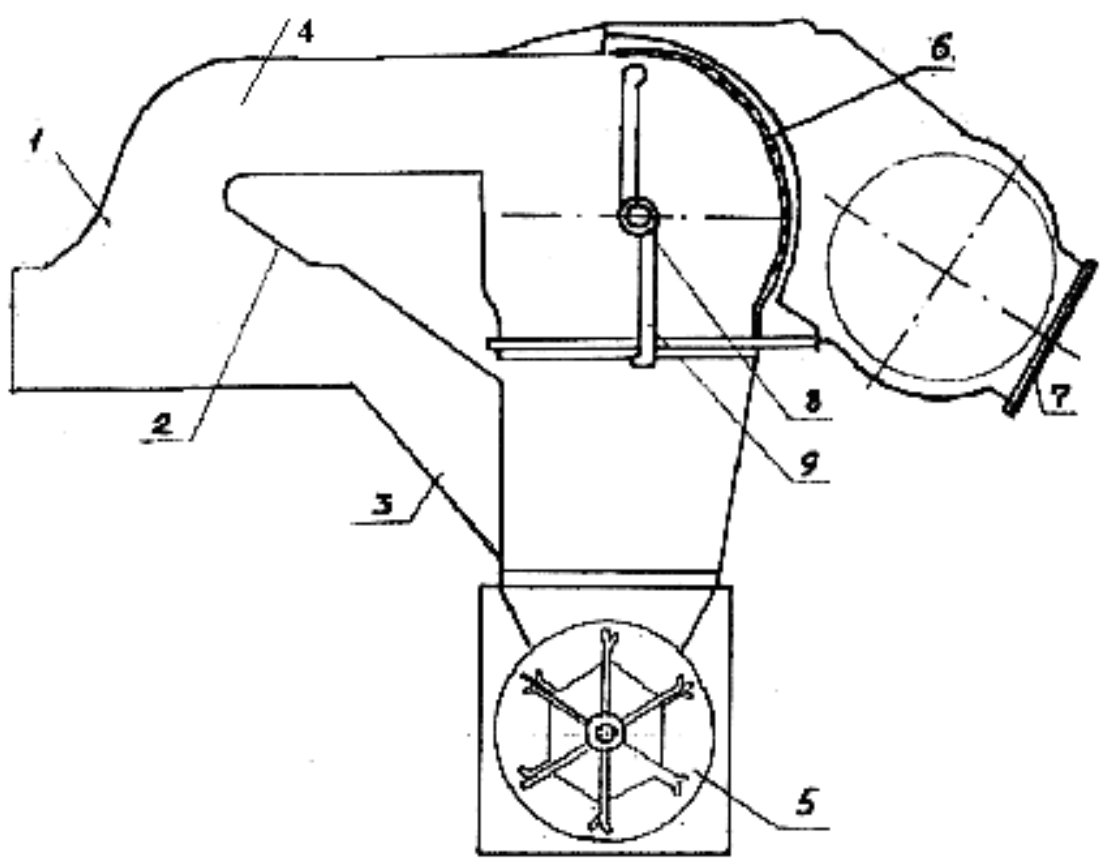

Figure 1. General view diagram of SX separator

1th separation chamber; 2 th revolving wall; 3 th inertial separation section; 4th seed cotton air inlet pipe; 5th vacuum-valve; 6 th grid surface; 7 th outlet pipe; 8th separation shaft; 9 th scraper.

\section{RESULTS AND DISCUSSION}

During the introduction of the improved separator, it was found that the bulk of the cotton mass moving through the separator inlet pipe falls into the vacuum valve by its own inertia (95-97\%) and $3-5 \%$ of the seed cotton moves through the air. As a result, it was argued that there was no need to install a mesh drum on the separator $[10,11,12]$. With this in mind, a sample copy of the improved separator was created. The proposed separator is shown in Figure 1. 
EPRA International Journal of Multidisciplinary Research (IJMR) - Peer Reviewed Journal

Volume: 7 | Issue: 1 |January 2021|| Journal D0I: 10.36713/epra2013 || SJIF Impact Factor: 7.032 ||ISI Value: 1.188

2 - rasmda keltirilgan SXM separatorida ishlab chiqarish jarayoni davomida sinov ishlari olib borildi.

Ishlab chiqarishda o’tkazilgan sinov natijalari, paxtaning ifloslik darajasi, namligi hamda chigitning mexanik shikastlanish darajalarini aniqlashga imkon berdi. Olingan natijalar 1 hamda 2 - jadvallarda keltirilgan.
The SXM separator shown in Figure 2 was tested during the manufacturing process.

The results of production tests allowed to determine the degree of contamination, moisture and mechanical damage to the cotton. The results are given in Tables 1 and 2 .

Table 1.

Changes in the degree of mechanical damage to the seed

\begin{tabular}{|c|c|c|c|c|c|}
\hline $\begin{array}{c}\text { The number of times the cotton passes through } \\
\text { the pipe }\end{array}$ & \multicolumn{4}{|c|}{$\begin{array}{c}\text { Depending on the change in the speed of the separator in the } \\
\text { inlet pipe, the degree of mechanical damage to the seed,\% }\end{array}$} \\
\cline { 2 - 6 } & $\begin{array}{c}\mathbf{2 7 , 3} \\
\mathbf{m} / \mathbf{s}\end{array}$ & $\mathbf{2 9 , 7} \mathbf{~ m / s}$ & $\mathbf{3 1 , 5} \mathbf{~ m / s}$ & $\mathbf{3 3 , 1} \mathbf{~ m / s}$ & $\mathbf{3 5 , 0} \mathbf{~ m / s}$ \\
\hline Preliminary indication of cotton & 1,62 & & & & \\
\hline 1 & 1,62 & 1,63 & 1,65 & 1,64 & 1,65 \\
\hline 2 & 1,62 & 1,67 & 1,64 & 1,65 & 1,67 \\
\hline 3 & 1,63 & 1,69 & 1,71 & 1,70 & 1,68 \\
\hline 4 & 1,68 & 1,72 & 1,74 & 1,72 & 1,76 \\
\hline
\end{tabular}

Experimental results

Table 2.

\begin{tabular}{|c|c|c|c|c|}
\hline $\begin{array}{l}\text { Cotton } \\
\text { sort }\end{array}$ & $\begin{array}{c}\text { The number of times the } \\
\text { cotton passes through the } \\
\text { pipe }\end{array}$ & $\begin{array}{c}\text { Degree of } \\
\text { mechanical } \\
\text { damage to the } \\
\text { seed in the } S X \\
\text { separator, } \%\end{array}$ & $\begin{array}{c}\text { Degree of } \\
\text { mechanical } \\
\text { damage to the } \\
\text { seed in the SXM } \\
\text { separator, } \% \\
\end{array}$ & $\begin{array}{c}\text { Amount of } \\
\text { waste, } \%\end{array}$ \\
\hline \multirow{5}{*}{1} & $\begin{array}{l}\text { Preliminary indication of } \\
\text { cotton }\end{array}$ & 1,35 & 0,73 & 4,55 \\
\hline & 1 & 1,46 & 0,74 & 3,82 \\
\hline & 2 & 1,53 & 0,79 & 3,50 \\
\hline & 3 & 1,63 & 0,81 & 3.32 \\
\hline & 4 & 1,76 & 0,84 & 3,28 \\
\hline \multirow{5}{*}{ W, \% 11.2} & $\begin{array}{l}\text { Preliminary indication of } \\
\text { cotton }\end{array}$ & 2,40 & 0,97 & 7,20 \\
\hline & 1 & 2,51 & 1,02 & 5,94 \\
\hline & 2 & 2,64 & 1,04 & 5,94 \\
\hline & 3 & 2,80 & 1,07 & 5,21 \\
\hline & 4 & 2,85 & 1,10 & 6,53 \\
\hline \multirow{4}{*}{ W, \% 16.7} & 1 & 2,54 & 1,03 & 6,53 \\
\hline & 2 & 2,71 & 1,07 & 6,19 \\
\hline & 3 & 2,90 & 1,10 & 5,89 \\
\hline & 4 & 2,97 & 1,15 & 5,67 \\
\hline \multirow{4}{*}{ W, \% 21.35} & 1 & 2,57 & 1,04 & 6,95 \\
\hline & 2 & 2,70 & 1,06 & 6,78 \\
\hline & 3 & 2,92 & 1,12 & 6,66 \\
\hline & 4 & 3,00 & 1,16 & 6,53 \\
\hline \multirow{5}{*}{ III } & $\begin{array}{l}\text { Preliminary indication of } \\
\text { cotton }\end{array}$ & 2,63 & 1,02 & 6,78 \\
\hline & 1 & 2,76 & 1,05 & 5,76 \\
\hline & 2 & 2,87 & 1,12 & 5,24 \\
\hline & 3 & 3,02 & 1,17 & 5,08 \\
\hline & 4 & 3,21 & 1,21 & 4,90 \\
\hline
\end{tabular}




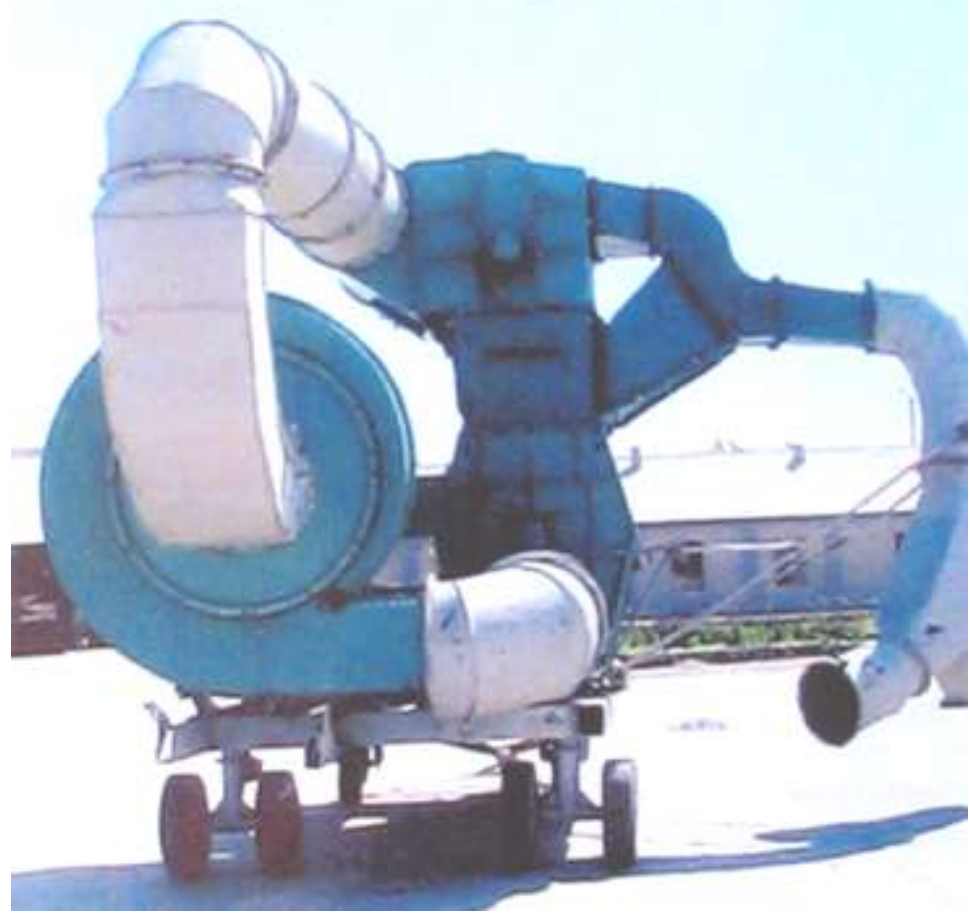

Figure 2. Side view of SXM separator.

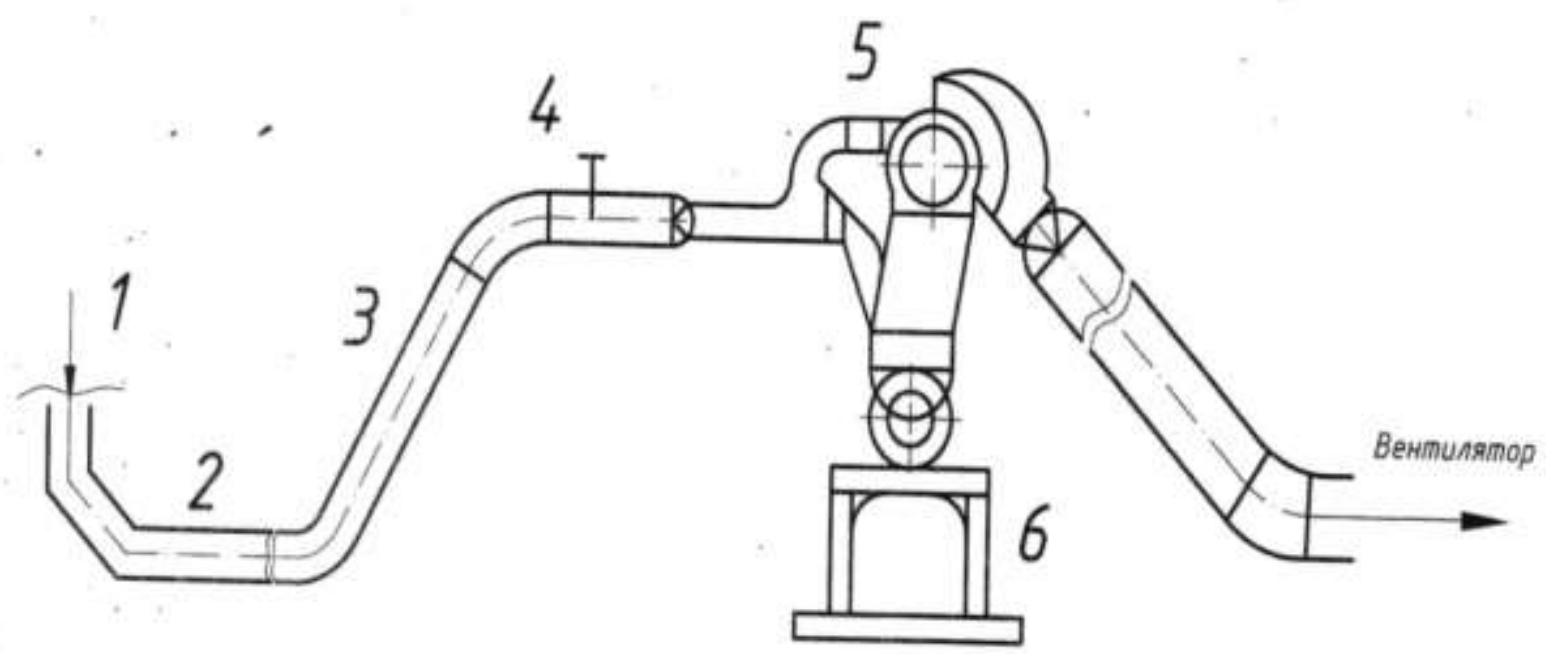

Figure 3. Experimental scheme of pneumatic transport device.

1th cotton transfer area; 2 th horizontal section; 3 th vertical section; 4th Prandtl pipeline; 5th separator; 6th hatch.

\section{CONCLUSIONS}

The analysis of the results in the tables shows that the improved SXM inertial separator allows to maintain the natural properties of cotton by $15-20 \%$ compared to the current SX separator, as well as to ensure a stable stable average of $15 \mathrm{t} / \mathrm{h}$. The implementation of this separator will reduce fiber loss by $0.23 \mathrm{~kg} / \mathrm{h}$ for high-grade cotton and by $1.83 \mathrm{~kg} / \mathrm{h}$ for low-grade cotton.

\section{REFERENCES}

1. Shodiev Z. O. Creation of a system of equal distribution of cotton flow in the separator SX. Dissertation for the degree of Candidate of Technical Sciences. Tashkent - 2010, 120 pages

2. Juraev Anvar and Rajabov Ozod, Analysis of the interaction of Fibrous Material with a Multifaceted Grid of the cleaner, International Journal of Recent Technology and Engineering, vol. 8, No 1, (2019), pp. 2661-2666.

3. O. I. Rajabov, A. S. Abrorov, N. I. Mirzaqulova, G. B. Zaripov, Kh. S. Ziyodullaev, An experimental study of the location of the grid bars cells installed under spiked cylinders in a cotton cleaner from small waste, 
IOP Conference Series: Materials Science and Engineering, (2020), 734(1) 012073.

4. O.I. Rajabov, F.A.Fazliddin, M. H. Gapparova and J. Shakhrillo, The influence of the location of the cells on the allocation of weed impurities for cleaning raw cotton from fine waste, IOP Conference Series: Materials Science and Engineering, (2020), 734(1) 012073.

5. Rajabov $O$, Fazliddin $K$, and Salimov Sh., Substantiation of Parameters of the Fibrous Material Cleaning Zone, International Journal of Engineering and Advanced Technology, vol. 9, No 3, (2020), pp. 1052-1057.

6. Jurayev A., and Rajabov O., Experimental study of the interactional of multifaceted and cylindrical spiky cylinder in cotton cleaner from small waste, International Journal of Advanced Research in Science, Engineering and Technology. Vol. 6, Issue 3, (2019), pp. 8376-8381.

7. Rajabov Ozod Isroilovich, The influence of the mode of movement of the pieces cotton when interacting with a cotton grid, International Journal of Advanced Research in Science, Engineering and Technology (India). Vol. 6, Issue 3, (2019), pp. 8455-8381.

8. Ozod Rajabov and Ziyodullo Shodiyev, Analysis of Small Fluctuations of a Multifaceted Mesh under the Influence of Technological Load from the Cleaned Cotton - Raw, International Journal of Advanced Research in Science, Engineering and Technology, Vol. 6, Issue 10, (2019), pp. 11396-11399.

9. Anvar Djuraev and Ozod Isroilovich Rajabov, Substantiation of the main parameters of the cylinder with multifaceted spiked of the cotton cleaner from small waste, International scientific and practical conference Innovative ideas of modern youth in science, (2019), USA. P. 149-151.

10. Mavlyanov Aybek Palvanbaevich, Rajabov Ozod Isroilovich and Yakubova Aziza Vakil qizi, Study of the influence of the parameters of the plastic grate on elastic supports with nonlinear stiffness on the oscillation frequency, International scientific and practical conference "Innovative ideas of modern youth in science", (2019), USA. P. 152-154.

11. Z. Shodiyev, A. Shomurodov and O. Rajabov. The results of the experimental nature of the vibrations of the grid cotton cleaner, IOP Conference Series: Materials Science and Engineering, 2020, 883 $012169 \quad$ https://doi.org/10.1088/1757$899 X / 883 / 1 / 012169$

12. Ozod Rajabov, Ziyodullo Shodiyev, Ikrom Inoyatov, Mastura Gapparova. Analysis of the Technological Process of Cleaning Raw Cotton from Small Trash, International Journal of Emerging Trends in Engineering Research, Volume 8. No. 9, September 2020, pp. 6022-6029. 